\title{
Research.
}

\section{Impact of Working Capital and Leverage on Profitability: a Comparison between Indonesia Ulama Council Fatwa and AAOIFI Sharia Standards}

\author{
Akhmad Sultoni'); Rahmat Mulyana); Saiful Anwar ${ }^{3)}$ \\ ${ }^{1,2,3)}$ Department of Islamic Business Management, Tazkia Institute, Bogor, Indonesia

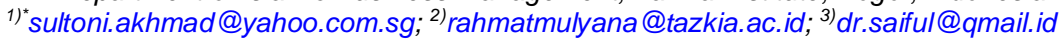

Received: May 10, 2021; Accepted: June 10, 2021; Published: June 30, 2021

* Corresponding author

To cite this article: Sultoni, A., Mulyana, R., Anwar, S.,(2021). Impact of working capital and leverage on profitability: a comparison between Indonesia Ulama Council Fatwa and AAOIFI Sharia Standards. The Accounting Journal of BINANIAGA. 6(1), 39-50. doi: 10.33062/ajb.v6i1.433

\begin{abstract}
This study aims to compare impact of working capital and leverage on profitability, based on different restrictions regulated by Indonesia Ulama Council's fatwa and AAOIFI sharia standards on the ratio of riba-based leverage to total assets. The objective of this paper is to compare and analyse which restrictions serves companies better. The research was conducted to companies listed in Indonesia Sharia Stock Index from 2012 until 2018 using Panel data regression. Samples were divided into three different groups based on the debt to assets ratio as an indicator of the riba based leverage $(\leq 30 \%, 30 \%-45 \%$ and $>45 \%)$. The result suggests that profitability of companies with leverage maximum $30 \%$, is not affected by working capital and leverage. While companies with leverage more than $30 \%$, has significant impact of working capital and leverage on their profitability. This study is limited to the companies listed in Indonesia Sharia Stock Index, with variables of days of accounts receivable, days of accounts payable, days of inventory, debt to assets ratio and return on assets. This study provides an empirical evidence that can be used to revisit the restrictions applied by Indonesia Ulama Council regarding the sharia stocks.
\end{abstract}

Keyword: working capital, leverage, profitability, sharia stocks.

\section{INTRODUCTION}

\section{Background}

The sharia industry is gaining its importance and growing at a fast pace. Islamic Finance Development Report issued by Thomson Reuters in 2018 shows that the total assets of sharia financial industry have grown 11\% year-on-year to 2.44 trillion USD, which equals to 6\% CAGR from 2012. Meanwhile as reported by Islamic Financial Service Board in 2019, sharia stock market has contributed $27 \%$ of total global sharia financial service industry, amounting 591.9 billion USD. In Indonesia, the development of sharia capital market was started back in 1997 when the first sharia mutual fund was issued, which then followed by the launching of Jakarta Islamic Index (JII) on the year of 2000. By 2018, the issuer of sharia stock in Indonesia was already 413 companies, an $8.12 \%$ growth from 2017. The market capitalization value of the sharia stocks was reported at 3,666.69 trillion IDR. In addition to that, the sharia stock holder in Indonesia have increased by $35.45 \%$ in 2017 , from 226,530 to 306,827 investors.

In the IDX Stock Index Handbook published in 2019, Indonesia Stock Exchange explains that stocks indices are a statistical measure, which represents of the whole 
movement of stock prices, selected based on certain criteria and methodology, and evaluated periodically. It is also mentioned in the report that the use of indices in Indonesia Stock Exchange has increased significantly from 1.49 trillion IDR of managed fund in 2014, into 14.51 trillion by the end of 2019 , which is an increase of ten times within the time span of five years. The growing importance of sharia stock requires clarity in terms of sharia compliance for companies considered having sharia stock.

Sharia stocks criteria in Indonesia is regulated by fatwa of Nasional Sharia Board of Indonesia Ulama Council number 20/DSN/-MUI/IV/2001. This fatwa states that for companies to issue sharia stocks, it has to follow certain rules, one of which is to limit the debt at maximum $45 \%$ of the total assets of the company. This restrictions is different with sharia standards number 21 issued by AAOIFI, which states that the issuance of sharia stocks is restricted to have debt at maximum $30 \%$ of the total market capitalization of the company. The difference of restrictions between these standards provides opportunities for further study and analysis. In the context of sharia finance, investors will need clearer and more solid guidance of what are allowed to be categorized as sharia stocks and what are not. This restriction on the debt to assets ratio is indicating the leverage of the firm, suggesting that there is a certain level of riba based leverage that is tolerated by Indonesia Ulama Council and AAOIFI for companies issuing stocks categorized as sharia stocks.

\section{Problem Formulation}

Since leverage has been recognized as one factor that has influence on the profitability level of a company, it is worth to look the restrictions on the leverage as one factor that is expected to have impact on the profitability of the company. Several studies have recognized the impact of the capital structure including leverage on the profitability of a company. In addition to that, working capital that also have influence on the level of leverage of a company, was also recognized as a factor that has an impact on the ability of a firm to make profit. Together, those factors are studied in this paper for their impact on the profitability of companies listed in Indonesia Sharia Stock Index. This study therefore aims to get better understanding of whether the difference in the restrictions of the sharia stocks will affect the relationship of working capital, leverage and profitability.

\section{REVIEW OF LITERATURE}

Preve and Sarria-Andelle (2010) defined working capital as one way for companies to fund their business operational activities. In that context, companies need working capital to fund the purchase of raw materials, salary payment of their employees, operational expenditures, and to fund credits given to customers (Paramasivan and Subramanian, 2009). Working capital management is basically about defining the levels of working capital necessary for a company, and deciding on the strategy or approach to fund them (Brigham and Ehrhardt, 2011).

There have been many studies about the relations of working capital, leverage and profitability done in several countries and markets. Jose et.al (1996) have done research to 2,718 companies in the time span of twenty years from 1974 to 1993 , regarding the relationship of cash conversion cycle with profitability of the company. In this research, the profitability was depicted by return on assets and return on equity. This research found out that there is a negative relationship between cash conversion cycle, return on assets and return on equity, and that the aggressive strategy of working capital taken by a company will likely to improve profit of that company. This result was further supported by study done by Wang (2002) to companies in Japan and Taiwan, which also found out that the cash conversion cycle, return on assets and return on equity are negatively related. That means every decrease in cash conversion cycle will result in increase of profitability of the company. In Belgium, Deloof (2003) also found that the gross operating income of a company has negative impact on the cash conversion cycle, days of

Akhmad Sultoni, Rahmat Mulyana and Saiful Anwar. Impact of working capital and leverage on profitability: a comparison between Indonesia Ulama Council Fatwa and AAOIFI Sharia Standards 
accounts receivable outstanding, days of accounts payable outstanding and days of inventory outstanding on gross operating income. Eljelly (2004) found the same result in the study for companies in Saudi Arabia, where the negative relations were much clearer on companies with high current ratio.

Padachi (2006) has done research on 58 small manufacturing companies in Mauritus, which showed result that working capital, specifically inventory and accounts receivable have relation to the companies' profitability. This research mentioned that high level of inventory and accounts receivable are related with the low level of profitability of a company. Vishnani and Shah (2007), and Akinlo (2012) also discovered another negative relation of accounts receivable with the profitability of a company. Meanwhile Ho and Mohd-Raff (2017) found interesting result from their study about determinant factors influencing performance of companies that are Sharia compliant and Sharia noncompliant. This research was done on 51 companies identified as Sharia compliant and 18 companies identified as non-Sharia compliant in Malaysia stock exchange between periods of 1999 until 2005. The result showed that high level of leverage has significant negative relationship with the profitability of companies that are Sharia non-compliant. Meanwhile for companies that are Sharia compliant, the leverage does not have significant relation, which caused by the restrictions of leverage applied by those companies.

\section{Sharia review}

Fatwa from National Sharia Board of Indonesia Ulama Council number 20/DSN$\mathrm{MUI/IV/2001} \mathrm{about} \mathrm{directive} \mathrm{of} \mathrm{investing} \mathrm{in} \mathrm{Sharia} \mathrm{mutual} \mathrm{fund,} \mathrm{explains} \mathrm{about} \mathrm{the}$ condition of a company that is prohibited from Sharia mutual fund, which are:

1. The debt to equity structure depends heavily on financing from riba-related source

2. The company has debt ratio over equity more than $82 \%$ (debt $45 \%$, equity $55 \%$ )

3. The management of the company is known to have acted against Islamic business principle

Meanwhile, Accounting and Auditing Organization for Islamic Financial Institutions (AAOIFI) Sharia standards number 21 states that for a company to be considered having Sharia stock, it must not own interest-based debt more than $30 \%$ of its market capitalization. This standard explains about the regulations regarding transactions in stocks. This standard mentions that basically it is forbidden to have and to be involved in the transactions of stock of a company that has business activity related with riba, even though the business activities are permitted by Sharia. But this standard gives some exceptions as follow:

1. The company does not state that one of its objectives is to deal in interest, or in prohibited goods or materials.

2. The collective amount raised as loan on interest (long-term or short-term) does not exceed $30 \%$ of the market capitalization of the company.

3. That the total amount of interest-taking deposits (short-term, medium-term or long-term) must not exceed $30 \%$ of the market capitalization of total equity.

4. The amount of income generated from prohibited component does not exceed $5 \%$ of the total income of the company irrespective of the income being generated by undertaking a prohibited activity, by ownership of a prohibited asset or in some other way.

It is worth to put a note that apparently, the regulations regarding the leverage limitations on Sharia stocks is different between sharia standards issued by AAOIFI and fatwa from Shari'sh Board of Indonesia Ulama Council. AAOIFI Sharia standards number 21 states that the company must not own interest based debt more than $30 \%$ of its

Akhmad Sultoni, Rahmat Mulyana and Saiful Anwar. Impact of working capital and leverage on profitability: a comparison between Indonesia Ulama Council Fatwa and AAOIFI Sharia Standards 
market capitalization to be excluded from prohibition of stock transactions that is allowed by Sharia principles. Meanwhile the fatwa number 20/DSN-MUI/IV/2001 from Sharia boards of Indonesia Ulama Council, the limitation for this interest-based debt a company has must not exceed $45 \%$ of its total assets (debt $45 \%$, equity $55 \%$ ).

This study aims to provide evidence which restrictions serves the companies better, by measuring impact on company's profitability from its leverage in addition to the working capital. This study propose the following hypothesis:

$\mathrm{HO}$ : There is a relationship between days of accounts receivable, days of accounts payable, days of inventory and leverage with return on assets.

$\mathrm{H} 1$ : There is no relationship between days of accounts receivable, days of accounts payable, days of inventory and leverage with return on assets.

The hypothesis will be tested and analysed to different companies grouped by level of leverage as per regulated by the fatwa and AAOIFI sharia standards to enable comparison

\section{METHODOLOGY}

This study is conducted by looking at the relation between working capital and leverage on profitability of the companies listed in the Indonesia Sharia Stock Index. The selected samples are taken from Indonesia Sharia Stock Index within the time span of 7 years from 2012 until 2018. The criteria of the companies selected for samples are as follow:

1. Consistently listed in the Indonesia Sharia Stock Index from 2012 until 2018.

2. The samples exclude companies in the financial sub-sector

The elimination of companies in financial sub-sector is based on the consideration that the financial industry is highly regulated, so it might need particular study on its own.

The data used for this study is acquired from the Indonesia Stock Exchange, which consists of:

1. Accounts Receivable

2. Inventory

3. Accounts Payable

4. Sales

5. Cost of Goods Sold

6. Total Liabilities

7. Earnings Before Interet and Tax

8. Total Assets

Those data are calculated to arrive at the variables used in this study, which are:

1. Independent Variables: Working Capital and Leverage

a. Days of Accounts Receivable: $\frac{\text { Accounts Receivable }}{\text { Sales }} \times 365$

b. Days of Accounts Payable: $\frac{\text { Accounts Payable }}{\text { Cost of Goods Sold }} \times 365$

c. Days of Inventory: $\frac{\text { Inventory }}{\text { Cost of Goods Sold }} \times 365$

d. Debt to Assets Ratio: Total Liabilities

2. Dependent Variable:

a. Return on Assets: $\frac{\text { Earnings Before Interest and Tax }}{\text { Total Assets }}$

Akhmad Sultoni, Rahmat Mulyana and Saiful Anwar. Impact of working capital and leverage on profitability: a comparison between Indonesia Ulama Council Fatwa and AAOIFI Sharia Standards 
The equation used in this study is described as follow:

$$
R O A=\beta_{0}+\beta_{1} A R+\beta_{2} A P+\beta_{3} I N V+\beta_{4} D A R
$$

To compare the different between AAOIFI Sharia standards and Indonesia Ulama Council fatwa on the restrictions of the riba exposure (interest-based liabilities), this study divides the samples into three groups based on the leverage (debt to assets ratio), in which the hypothesis will be analysed to:

1. Companies with debt to assets ratio up to $30 \%$

2. Companies with debt to assets ratio between $30 \%$ and $45 \%$

3. Companies with debt to assets ratio more than $45 \%$

Panel data regression is used in this study. Gujarati (2003) mentions that panel data has some benefits as follow:

1.Panel data enables heterogeneous individual variables included in the equation.

2.By combining time series and cross section, the usage of panel provides data that are more informative, more diverse, less collinearity between variables, more degree of freedom and efficiency

3.Panel data has the ability to capture the dynamic of change, by doing repetitive observation on time series data

4.Panel data can identify and measure impacts that would not be able to reveal if using time series data only or cross section data only

5.Panel data enables research done on more complicated behaviour models

6. Panel data enables research done on many variables, which minimize the bias on the result.

This study is conducted on 151 companies listed in Indonesia Sharia Stock Index during time span from 2012 until 2018. Furthermore, the companies were grouped based on their debt to assets ratio into three groups $(\leq 30 \%, 30 \%-45 \%$, and $>45 \%)$. The groups of the companies are shown in the table 1:

Table 1. Debt to Assets Ratio Group

\begin{tabular}{lllllllll}
\hline Debt to Assets Ratio & $\mathbf{2 0 1 2}$ & $\mathbf{2 0 1 3}$ & $\mathbf{2 0 1 4}$ & $\mathbf{2 0 1 5}$ & $\mathbf{2 0 1 6}$ & $\mathbf{2 0 1 7}$ & $\mathbf{2 0 1 8}$ & Total \\
\hline$\leq 30 \%$ & 44 & 38 & 42 & 41 & 46 & 42 & 40 & 293 \\
\hline $30 \%-45 \%$ & 49 & 49 & 44 & 48 & 48 & 52 & 47 & 337 \\
\hline$>45 \%$ & 58 & 64 & 65 & 62 & 57 & 57 & 64 & 427 \\
\hline Total & 151 & 151 & 151 & 151 & 151 & 151 & 151 & 1057 \\
\hline
\end{tabular}

The panel data regression was applied for each group of the companies. The process involves selecting the best regression model to use, either common effect model, fixed effect model or random effect model. The selection of regression model used on each group of companies is shown below:

Table 2. Selected Regression Model

\begin{tabular}{ll}
\hline Debt to Assets Ratio & Selected Regression Model \\
\hline$\leq 30 \%$ & Random Effect Model \\
\hline $30 \%-45 \%$ & Fixed Effect Model \\
\hline$>45 \%$ & Random Effect Model \\
\hline
\end{tabular}

Akhmad Sultoni, Rahmat Mulyana and Saiful Anwar. Impact of working capital and leverage on profitability: a comparison between Indonesia Ulama Council Fatwa and AAOIFI Sharia Standards 
The Accounting Journal of BINANIAGA Vol. 06, No. 01, June 2021

p-ISSN: 2527-4309, e-ISSN: 2580-1481

$5^{\text {th }}$ Accreditation Rating: January 14, 2019 - January 13, 2024

\section{RESULT AND DISCUSSIONS}

The result of the study for each group is explained as follow:

1. Result for groups of companies with debt to assets ratio $\leq 30 \%$

This group uses random effect model regression, with equation result as follow:

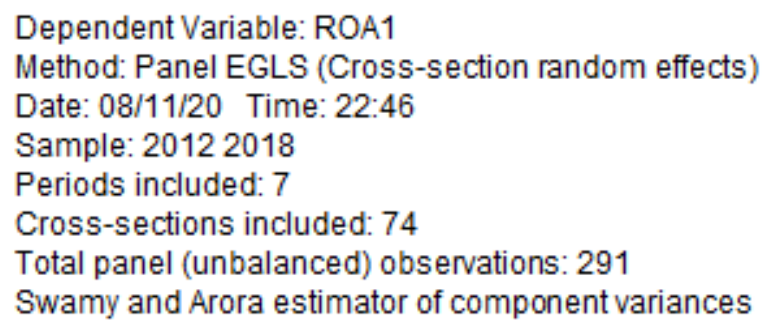

\begin{tabular}{crrrr}
\hline \hline Variable & Coefficient & Std. Error & t-Statistic & Prob. \\
\hline \hline C & 1.287182 & 0.265009 & 4.857119 & 0.0000 \\
AR1 & -0.041966 & 0.083799 & -0.500801 & 0.6169 \\
AP1 & -0.004245 & 0.096502 & -0.043986 & 0.9649 \\
INV1 & 0.051208 & 0.069552 & 0.736248 & 0.4622 \\
DAR1 & -0.550525 & 0.234769 & -2.344967 & 0.0197 \\
\hline \hline
\end{tabular}

$\mathrm{ROA}=1.287182-0.041966(\mathrm{AR})-0.004245(\mathrm{AP})+0.051208(\mathrm{INV})-0,550525(\mathrm{DAR})$

Where:

- $\quad \beta_{0}=1.287182$ is the constant or value of dependent variable $\mathrm{ROA}$ if the value of independent variables AR, AP, INV and DAR were zero

- $\quad \beta_{1}=-0.041966$ is the regression coefficient for days of accounts receivable. This coefficient explains that every increase in the days of accounts receivable, while assuming the other independent variables are constant, the return on assets is predicted to decrease by 0.041966 in group of companies with debt to assets ratio $\leq 30 \%$

- $\quad \beta_{2}=-0.004245$ is the regression coefficient for days of accounts payable. This explains that every increase in days of accounts payable, assuming other dependent variables are constant, will result in decrease of return on assets by 0.004245 in group of companies with debt to assets ratio $\leq 30 \%$

- $\quad \beta_{3}=0.051208$ is the coefficient regression for days of inventory. This means that every increase in days of inventory, while assuming other dependent variables are constant, will result in increase of return on assets by 0.051208 in group of companies with debt to assets ratio $\leq 30 \%$.

- $\quad \beta_{4}=-0.550525$ is the coefficient regression for leverage/debt to assets ratio. This explains that every increase in debt to assets ratio, while assuming other dependent variables are constant, will result in decrease of return on assets by 0.550525 in group of companies with debt to assets ratio $\leq 30 \%$.

The value of R-squared and the F-statistic for this group of companies are shown in the following table:

Akhmad Sultoni, Rahmat Mulyana and Saiful Anwar. Impact of working capital and leverage on profitability: a comparison between Indonesia Ulama Council Fatwa and AAOIFI Sharia Standards 


\begin{tabular}{llll}
\hline \hline & Weighted Statistics & \\
\hline \hline R-squared & 0.021367 & Mean dependent var & 0.437065 \\
Adjusted R-squared & 0.007680 & S.D. dependent var & 0.422762 \\
S.E. of regression & 0.406212 & Sum squared resid & 47.19223 \\
F-statistic & 1.561107 & Durbin-Watson stat & 1.937152 \\
Prob(F-statistic) & 0.184788 & & \\
\hline \hline
\end{tabular}

The value of $\mathrm{R}$-squared is 0.021367 , which means that in the group of companies where the debt to assets ratio is $\leq 30 \%$, the independent variables explain $2.1 \%$ of return on assets, while the other $97.9 \%$ is affected by other factors not included in this study. The F-statistic value is 0.184788 , which means that for this group of companies with debt to assets ratio $\leq 30 \%$, the $\mathrm{HO}$ is rejected, and $\mathrm{H} 1$ is accepted, which means that the working capital and leverage do not have relations with the profitability of the firm included in the group of leverage up to $30 \%$.

This result can be implied that for companies with debt to assets ratio does not exceed $30 \%$, the level of working capital and leverage of the companies does not have any impact on the profitability. This means that for companies who have leverage $30 \%$ at maximum, the profitability is the result of its ability to operate the business with good margin and efficient operation, not impacted by its working capital and leverage level.

2. Result for groups of companies with debt to assets ratio $30 \%-45 \%$

This group uses fixed effect model regression, with equation result as follow:

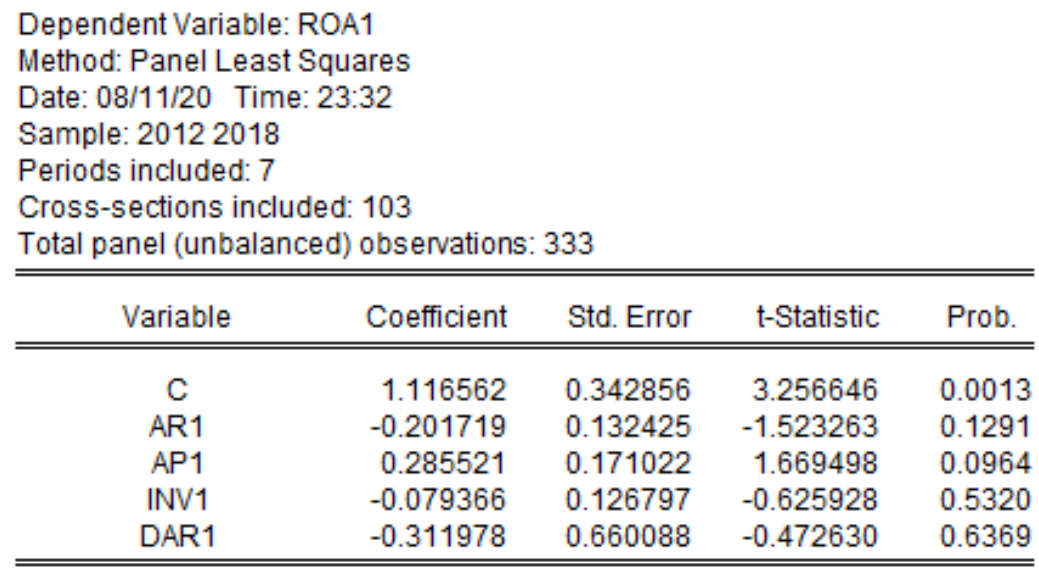

$\mathrm{ROA}=1.116562-0.201719(\mathrm{AR})+0.285521(\mathrm{AP})-0.079366(\mathrm{INV})-0.311978(\mathrm{DAR})$ Where:

- $\quad \beta_{0}=1.116562$ is the constant or value of dependent variable ROA if the value of independent variables AR, AP, INV and DAR were zero

- $\quad \beta_{1}=-0.201719$ is the regression coefficient for days of accounts receivable. This coefficient explains that every increase in the days of accounts receivable, while assuming the other independent variables are constant, the return on assets is predicted to decrease by 0.201719 in group of companies with debt to assets ratio $30 \%-45 \%$

- $\quad \beta_{2}=0.285521$ is the regression coefficient for days of accounts payable. This explains that every increase in days of accounts payable, assuming other

Akhmad Sultoni, Rahmat Mulyana and Saiful Anwar. Impact of working capital and leverage on profitability: a comparison between Indonesia Ulama Council Fatwa and AAOIFI Sharia Standards 
dependent variables are constant, will result in increase of return on assets by 0.285521 in group of companies with debt to assets ratio $30 \%-45 \%$

- $\quad \beta_{3}=-0.079366$ is the coefficient regression for days of inventory. This means that every increase in days of inventory, while assuming other dependent variables are constant, will result in decrease of return on assets by 0.079366 in group of companies with debt to assets ratio 30\% - 45\%.

- $\quad \beta_{4}=-0.311978$ is the coefficient regression for leverage/debt to assets ratio. This explains that every increase in debt to assets ratio, while assuming other dependent variables are constant, will result in decrease of return on assets by 0.311978 in group of companies with debt to assets ratio $30 \%$ $45 \%$

The value of R-squared and the F-statistic for this group of companies are shown in the following table:

Effects Specification

\begin{tabular}{lrll}
\hline \hline Cross-section fixed (dummy variables) & & \\
\hline \hline R-squared & 0.586710 & Mean dependent var & 0.983986 \\
Adjusted R-squared & 0.392867 & S.D. dependent var & 0.515771 \\
S.E. of regression & 0.401883 & Akaike info criterion & 1.269722 \\
Sum squared resid & 36.50117 & Schwarz criterion & 2.493359 \\
Log likelihood & -104.4087 & Hannan-Quinn criter. & 1.757655 \\
F-statistic & 3.026719 & Durbin-Watson stat & 2.348025 \\
Prob(F-statistic) & 0.000000 & & \\
\hline \hline
\end{tabular}

The value of $R$-squared is 0.586710 , which means that in the group of companies where the debt to assets ratio is $30 \%-45 \%$, the independent variables explain $58.7 \%$ of return on assets, while the other $41.3 \%$ is affected by other factors not included in this study. The F-statistic value is 0.000000 , which means that for this group of companies with debt to assets ratio $30 \%-45 \%$, the $\mathrm{HO}$ is accepted, and $\mathrm{H} 1$ is rejected, which means that the working capital and leverage have relations with the profitability of the firm included in the group of leverage between $30 \%$ and $45 \%$.

This result can be implied that for companies with debt to assets ratio between $30 \%$ and $45 \%$, the profitability is impacted by their level of working capital and leverage. This means that in addition of being able to operate the business in a good margin, these companies also need to monitor the level of working capital and leverage, as they can impact their profitability as well.

3. Result for groups of companies with debt to assets ratio $>45 \%$ This group uses random effect model regression, with equation result as follow:

$\mathrm{ROA}=0.973745-0.068910(\mathrm{AR})-0.173243(\mathrm{AP})+0.053419(\mathrm{INV})+1.497160(\mathrm{DAR})$

Where:

- $\beta_{0}=0.973745$ is the constant or value of dependent variable $R O A$ if the value of independent variables AR, AP, INV and DAR were zero

- $\quad \beta_{1}=-0.068910$ is the regression coefficient for days of accounts receivable. This coefficient explains that every increase in the days of accounts receivable, while assuming the other independent variables are constant, the return on assets is predicted to decrease by 0.068910 in group of companies with debt to assets ratio $>45 \%$

Akhmad Sultoni, Rahmat Mulyana and Saiful Anwar. Impact of working capital and leverage on profitability: a comparison between Indonesia Ulama Council Fatwa and AAOIFI Sharia Standards 
- $\quad \beta_{2}=-0.173243$ is the regression coefficient for days of accounts payable. This explains that every increase in days of accounts payable, assuming other dependent variables are constant, will result in decrease of return on assets by 0.173243 in group of companies with debt to assets ratio > $45 \%$

- $\quad \beta_{3}=0.053419$ is the coefficient regression for days of inventory. This means that every increase in days of inventory, while assuming other dependent variables are constant, will result in increase of return on assets by 0.053419 in group of companies with debt to assets ratio $>45 \%$.

- $\quad \beta_{4}=1.497160$ is the coefficient regression for leverage/debt to assets ratio. This explains that every increase in debt to assets ratio, while assuming other dependent variables are constant, will result in increase of return on assets by 1.497160 in group of companies with debt to assets ratio > 45\%

Dependent Variable: ROA1

Method: Panel EGLS (Cross-section random effects)

Date: 08/12/20 Time: 00:02

Sample: 20122018

Periods included: 7

Cross-sections included: 98

Total panel (unbalanced) observations: 421

Swamy and Arora estimator of component variances

\begin{tabular}{crrrr}
\hline \hline Variable & Coefficient & Std. Error & t-Statistic & Prob. \\
\hline \hline C & 0.973745 & 0.245433 & 3.967452 & 0.0001 \\
AR1 & -0.068910 & 0.073259 & -0.940639 & 0.3474 \\
AP1 & -0.173243 & 0.084460 & -2.051182 & 0.0409 \\
INV1 & 0.053419 & 0.049267 & 1.084259 & 0.2789 \\
DAR1 & 1.497160 & 0.452520 & 3.308492 & 0.0010 \\
\hline \hline
\end{tabular}

The value of R-squared and the F-statistic for this group of companies are shown in the following table:

Weighted Statistics

\begin{tabular}{llll}
\hline \hline & & & \\
R-squared & 0.058548 & Mean dependent var & 0.631448 \\
Adjusted R-squared & 0.049496 & S.D. dependent var & 0.470754 \\
S.E. of regression & 0.456842 & Sum squared resid & 86.82113 \\
F-statistic & 6.467704 & Durbin-Watson stat & 1.844659 \\
Prob(F-statistic) & 0.000047 & & \\
\hline \hline
\end{tabular}

The value of $R$-squared is 0.058548 , which means that in the group of companies where the debt to assets ratio $>45 \%$, the independent variables explain $5.8 \%$ of return on assets, while the other $94.2 \%$ is affected by other factors not included in this study. The F-statistic value is 0.000047 , which means that for this group of companies with debt to assets ratio $>45 \%$, the $\mathrm{HO}$ is accepted, and $\mathrm{H} 1$ is rejected, which means that the working capital and leverage have relations with the profitability of the firm included in the group of leverage more than $45 \%$.

Similar with the group of companies with leverage ranging between $30 \%$ and $45 \%$, profitability companies with debt to assets ratio more than $45 \%$ is impacted by the level of working capital and leverage they have. This means that in these companies need to take into account the level of working capital and leverage, in addition of their ability to operate the business to provide good margin.

Akhmad Sultoni, Rahmat Mulyana and Saiful Anwar. Impact of working capital and leverage on profitability: a comparison between Indonesia Ulama Council Fatwa and AAOIFI Sharia Standards 


\section{CONCLUSION AND RECOMMENDATION}

The result of the study can be drawn into conclusion that the relations between working capital and leverage to the profitability of a company depends on its leverage level. The study shows that the limit for working capital and leverage to have impact on profitability of a company is at $30 \%$ leverage. The study shows that in the group of companies with leverage maximum at $30 \%$, the profitability is not affected by the working capital and the leverage of the company. This means that for companies with leverage maximum at $30 \%$, their strategy in funding their working capital will not affect their profitability. In other words, companies with debt to assets ratio not exceeding $30 \%$ will have profitability that is impacted only by its ability to manage its performance without any influence from its approach in funding its working capital. Meanwhile, for the companies with leverage more than $30 \%$, their ability to generate profit will be impacted by their choice of strategy in funding the working capital.

This result supports the study done by Ho and Mohd-Raff (2017), which showed that the limitations of leverage level in Sharia-compliant companies makes the leverage does not affect the performance of the companies. In relation to the restrictions of riba related liability structure as regulated by AAOIFI and fatwa of Indonesia Ulama Council, the study shows result in favour of the regulations stated in Sharia standards of AAOIFI. In this regards, the $45 \%$ limit of interest-based loan set by fatwa of Indonesia Ulama Council regarding Sharia stocks is considered too loose, because in this level of leverage, the ability of a company to generate profits will be influenced by its decision on strategy to fund the working capital and the leverage it has.

\section{Limitations and future research suggestions}

This study only includes working capital and leverage as the variables that influence the profitability of a company, which are shown by the small value of R-squared in the group of companies with debt to assets ratio $\leq 30 \%$ and $>45 \%$. This limits the factors explaining the relationship between working capital and leverage to the profitability of a company. Future studies in the field of Sharia stocks might want to include other variables to explain the influence on the profitability better. The scope of the studies can also be extended into broader population of sharia-compliant companies outside Indonesia.

\section{Benefit of the study}

This study can give benefits for several parties as follow:

1. Sharia business practitioners might want to pay attention to the limit of leverage they want to apply, to manage the impact of working capital and leverage to the profitability of the companies.

2. Indonesia Ulama Council might want to review the fatwa regulating the limit of interest-based liability permitted for Sharia stocks issuing companies, and aligning with $\mathrm{AAOIFI}$ in this regard.

\section{REFERENCES}

Akinlo, O.O. (2012). Effect of Working Capital on Profitability of Selected Quoted Firms in Nigeria. Global Business Review. Vol 13, pp. 367.

Brigham, E.F. and Ehrhardt, M.C. Financial Management, Theory and Practice. Thirteenth Edition. South-Western Cengage Learning. 2011.

Deloof, M. (2003). Does Working Capital Management Affect Profitability of Belgian Firms. Journal of Business Finance and Accounting.Vol. 30 No.3 \& 4. pp 573-587.

Akhmad Sultoni, Rahmat Mulyana and Saiful Anwar. Impact of working capital and leverage on profitability: a comparison between Indonesia Ulama Council Fatwa and AAOIFI Sharia Standards

Page : 48 
Eljelly, A.M.A. (2004). Liquidity - Profitability Tradeoff: An Empirical Investigation in an Emerging Market. International Journal of Commerce and Management. Vol. 14 No. 2 pp. $48-61$.

Ho, C.S.F., Mohd-Raff, N.E.N (2017). External and Internal Determinants of Performances of Shariah and non-Shariah Compliant Firms. International Journal of Islamic and Middle Eastern Finance and Management. Vol. 12 No. 2. pp. 236253

Jose M.L, Lancaster C, and Stevens J.L (1996). Corporate Returns and Cash Conversion Cycles. Journal of Economics and Finance. Vol. 20 No.1. pp. 33-46.

Padachi, K. (2006). Trends in Working Capital Management and its Impact on Firms' Performance: An Analysis of Mauritian Small Manufacturing Firms. International Review of Business Research Papers. Vo.2 No. 2. pp. 45 -58.

Paramasivan, C. \& Subramanian, T. :"Financial Management". New Age International Publishers. 2009.

Preve, Lorenzo A \& Sarria-Andelle, Virginia: "Working Capital Management". Financial Management Association Survey and Synthesis Series. Oxford University Press. 2010.

Vishnani, S. and Shah, B. (2007). Impact of Working Capital Management Policies on Corporate Performance - An Empirical Study. Global Business Review. Vol 8, pp. 267.

Wang, Y.J. (2002). Liquidity Management, Operating Performance, and Corporate Value: Evidence from Japan and Taiwan. Journal of Multinational Financial Management. Vol. 12. pp $159-169$.

Accounting and Auditing Organization for Islamic Financial Institutions (2017). Sharia Standard No.21. Financial Paper (Shares and Bonds). Pp 563-564.

National Sharia Board Indonesia Ulama Council (2001). National Sharia Board Fatwa Number: 20/DSN-MUI/IV/2001 About Investment Implementation Guidelines for Sharia Mutual Funds. Article 8 \& 10.

Thomson Reuters (2018). Islamic Finance Development Report 2018.

Akhmad Sultoni, Rahmat Mulyana and Saiful Anwar. Impact of working capital and leverage on profitability: a comparison between Indonesia Ulama Council Fatwa and AAOIFI Sharia Standards 
The Accounting Journal of BINANIAGA Vol. 06, No. 01, June 2021

p-ISSN: 2527-4309, e-ISSN: 2580-1481

$5^{\text {th }}$ Accreditation Rating: January 14, 2019 - January 13, 2024

This page intentionally be emptied

Akhmad Sultoni, Rahmat Mulyana and Saiful Anwar. Impact of working capital and leverage on profitability: a comparison between Indonesia Ulama Council Fatwa and AAOIFI Sharia Standards

Page : 50 